\section{Commentary: Let's just celebrate this win}

\author{
Jacob A. Klapper, MD, FACS
}

Pandemics are not new in human history, and the hysteria, rumor, and abundant falsehoods that are a natural byproduct of these periods have produced unusual and sometimestragic examples of human behavior. Just as in times past, our reflexive nature, born out of our need to survive, spurs us to actions, some of which make sense and others...not so much. For instance, I still don't understand the run on toilet paper. What makes our current experience particularly unique is how it occurs in era in which the diffusion of information, both good and bad, can occur instantaneously. Inescapable is right. In fact, just as inescapable as the virus itself, and perhaps just as deadly.

Just as those outside of medicine, we as health care professionals are not immune. After all, coronavirus disease 2019 (COVID-19)-related articles have been not a topic in our journals but have become the topic. Whereas 30 years ago we may have been relegated to waiting for the print edition, the websites of every major journal are now awash in virus-related articles that inundate and can easily cloud our judgment of what makes sense and what is just nonsensical. Anecdotal evidence proliferates and is dispersed into the ether of our modern information age. Can we be faulted for our desire to spread what seems to be relevant knowledge? No. After all, no one designs a large-scale trial in anticipation of the next disease.

Should we consider the reputed success surrounding each novel intervention with a jaundiced eye? Yes.

Thus, case reports, such as the one published by Al-Qudsi and colleagues, ${ }^{1}$ are of particular importance in the current environment. The clinical scenario that they present is one

\footnotetext{
From the Division of Cardiothoracic Surgery, Duke University Medical Center, Durham, NC

Disclosures: The author reported no conflicts of interest.

The Journal policy requires editors and reviewers to disclose conflicts of interest and to decline handling or reviewing manuscripts for which they may have a conflict of interest. The editors and reviewers of this article have no conflicts of interest.

Received for publication June 21, 2020; revisions received June 21, 2020; accepted for publication June 23, 2020; available ahead of print July 13, 2020.

Address for reprints: Jacob A. Klapper, MD, FACS, Division of Cardiothoracic Surgery, DUMC 3954, Durham, NC 27710 (E-mail: Jacob.klapper@duke.edu).

J Thorac Cardiovasc Surg 2021;161:e43

0022-5223/\$0.00

Published by Elsevier Inc. on behalf of The American Association for Thoracic Surgery

https://doi.org/10.1016/j.jtcvs.2020.06.103
}

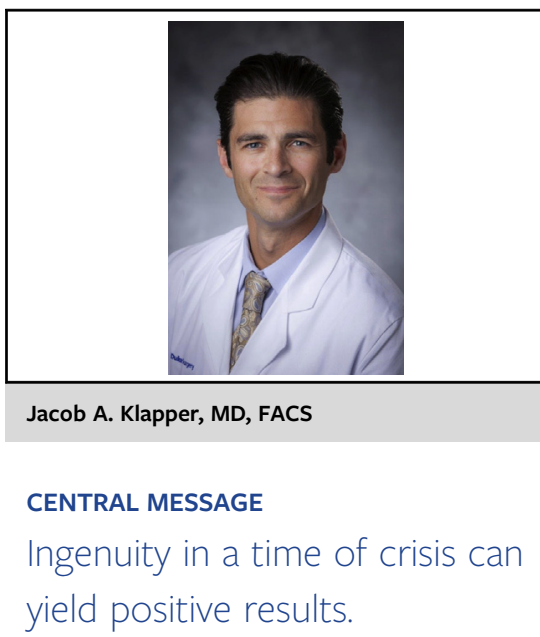

that we have all seen by now, but the use of a cytokine filter is particularly intriguing, given that it is the "cytokine storm" that appears to be most injurious. Whether their use of the filter actually reversed the course of events for this patient or not is debatable, since this intervention did not occur in a vacuum. Regardless, their narrative is to be commended, since it reflects thoughtful clinical decisionmaking that cohesively mixes a rationale treatment option with regard for patient safety.

Extracorporeal membrane oxygenation, by itself, has by now become an established therapy for acute respiratory distress syndrome. On a macro level, what a case report like this highlights is an exciting new potential area for this technology; one where it becomes the vehicle for administering therapeutic adjuncts. As the current report demonstrates, innovation and progress can be born out of calamitous times; the old "necessity is the mother of invention." In addition, it reveals the ingenuity of the human mind and what can be done when knowledge is applied for the greater good. Ultimately, the benefits of this filter need to be tested in standard sober way that we conduct ourselves in medicine, but for now, in these tough times, let's just celebrate this win.

\section{Reference}

1. Al-Qudsi O, Whitson B, Bhatt A, Chucta S, Tripathi R. A case of cytokine hemofiltration and extracorporeal life support as treatment of coronavirus disease 2019 (COVID-19) respiratory failure. J Thorac Cardiovasc Surg. 2021;161: e39-41. 